\title{
Remittances and the Brain Drain: Do More Skilled Migrants Remit More?
}

\begin{abstract}
Riccardo Faini
In most destination countries, immigration policies are tilted more and more in favor of skilled individuals. Whether this shift hurts economic prospects in sending countries, as argued by the traditional brain drain literature, is somewhat controversial. The most recent literature focuses on the link between skilled outmigration and educational achievements in the home country. This article emphasizes a different channel. It considers the argument that skilled migrants raise economic welfare at home by sending a relatively larger flow of remittances. While skilled migrants typically earn more, and so might be expected to remit more, they are also likely to spend more time abroad and to reunite with their close family in the host country. These second two factors should be associated with a smaller propensity to remit. Thus, the sign of the impact of the brain drain on total remittances is an empirical question. A simple model has been developed showing that skilled migrants may indeed have a lower propensity to remit from a given flow of earnings. An empirical equation of remittances is estimated as a measure of the brain drain in developing countries using the Docquier and Marfouk (2004) data set. Evidence is found that the brain drain is associated with a smaller propensity to remit. JEL codes: F02, F22
\end{abstract}

Immigration policies in receiving countries are increasingly tilted in favor of skilled migrants (Beine, Docquier, and Rapoport 2003; OECD 2003). This trend is raising considerable concern among policymakers in developing countries, wary of having to bear the cost of educating and then losing their most entrepreneurial and talented workers. Anecdotal evidence is startling. According to Stalker (1994), Jamaica had to train five doctors to retain

Editor's note: This paper was submitted in September 2006. The author received comments in November. Riccardo Faini passed away suddenly on January 20, 2007. This version was revised by the editor and reflects helpful comments from three referees. The editor thanks David McKenzie for suggestions and Céline Carrère and Mario Piacentini for help.

Riccardo Faini was a professor of political economy at Università di Roma Tor Vergata and a research fellow at the Institute for the Study of Labor (Bonn) and the Center for Economic Policy Research (London). He wished to thank seminar participants at the Royal Economic Society, the Global Trade Analysis Project Conference in Lubeck, the Poverty Redirection and Economic Management Conference at the World Bank, and anonymous reviewers for helpful comments. He also wanted to thank Domenico De Palo for outstanding research assistance.

THE WORLD BANK ECONOMIC REVIEW, VOL. 21, NO. 2, pp. 177-191

doi:10.1093/wber/lhm006

Advance Access Publication 24 May 2007

(C) The Author 2007. Published by Oxford University Press on behalf of the International Bank for Reconstruction and Development / THE WORLD BANK. All rights reserved. For permissions, please e-mail: journals.permissions@oxfordjournals.org 
just one, and Grenada, 22. Central American and Caribbean countries are particularly affected by the brain drain, presumably because of their proximity to the United States. African countries have also suffered from a massive emigration of their skilled workers, with 30 percent of the best educated people working abroad, chiefly in the European Union. Extensive confirmation of these trends is given in the article by Docquier, Lohest, and Marfouk in (2007).

The brain drain is not an unmitigated curse, however, at least not in theory. The possibility for educated migrants to move abroad should raise the returns to education and, in the end, may even lead to an increase in the number of educated workers who stay at home (Bhagwati and Hamada 1974; Bhagwati 1976; Mountford 1997; Stark, Helmenstein, and Prskawetz 1997, 1998). Moreover, skilled migrants will typically earn more and may therefore remit more (World Bank 2003, 2006), relieving the foreign exchange constraint at home and thus fostering growth. ${ }^{1}$

This article takes a fresh look at whether the brain drain is associated with a larger flow of remittances. It finds that the conventional wisdom, as often happens, is wrong. There is no evidence that skilled workers remit more. This is not so simply because they come from relatively wealthy families. It also reflects the fact that skilled migrants are more likely to spend a longer time abroad, weakening their ties with the home country. As a consequence, the growing bias in receiving countries toward skilled migration may reduce the flow of remittances to sending countries, although this negative effect is not statistically significant.

\section{The Behavior of Skilled Migrants: Some Descriptive EvidenCE}

The impact of the emigration of highly skilled people on the economic prospects of origin countries is highly controversial. The early literature (Bhagwati 1976) tended to conclude that the brain drain was detrimental to sending countries. Even when skilled workers were unemployed at home, their social marginal productivity was not necessarily nil, as they could move internally and become productively employed. More crucially, the costs of education are

1. Even the impact of remittances on home country growth has been questioned, however. Much of the descriptive literature on remittances argues that they are used "unproductively," citing micro evidence that remittance income is often wasted on conspicuous expenditures (see, however, Adams 1991, 1998, for an opposite view). More elaborate models conclude that higher remittances may exacerbate moral hazard problems on the recipient side and discourage work effort. Growth may fall as a result. Building on this argument, Chami, Fullenkamp, and Jahjah (2003) argue that remittances are not an effective source of capital for development. Chami, Fullenkamp, and Jahjah (2003) and Faini (2002) give some (conflicting) evidence on the link between growth and remittances. See also Rajan and Subramanian $(2005 \mathrm{a}, 2005 \mathrm{~b})$ for an insightful discussion of the different growth impacts of aid and remittances. 
typically borne by home country taxpayers. The more recent literature is more nuanced. Mountford (1997), Stark, Helmenstein, and Prskawetz (1997, 1998), and Beine, Docquier, and Rapoport $(2001,2003)$ argue that the possibility of migrating abroad raises the returns to education and may boost investment in education. It could then well be that, ex post, after some educated workers have moved abroad, the home country share of educated workers rises rather than falls.

A different line of argument emphasizes the role of remittances. According to World Bank (2003), the negative effects of the brain drain are somewhat offset by inward remittances from migrants. There is indeed some (limited) evidence that remittances tend to increase with the level of skills (Johnson and Whitelaw 1974; Rempel and Lobfell 1978). Presumably, skilled migrants earn more and therefore, other things being equal, are likely to remit more. However, there are many unresolved issues with this strand of literature. First, the evidence is not unequivocal, with Rodriguez and Horton (1994) for instance showing for the Philippines that the education level of migrants has no impact on the amount of remittances. Second, skilled workers may come from wealthier and more educated families and therefore have less of an incentive to remit. Finally, they may spend a longer time abroad, ${ }^{2}$ either because they are more eager to reunite with their families in the host country or because they face fewer constraints in doing so. Indeed, a typical finding in the literature is that the flow of remittances tends to decline with the length of migrants' stay (Lucas and Stark 1985).

There is substantive evidence that skilled migrants stay longer in the host country. Borjas and Bratsberg (1996) show that, under fairly general conditions, return migration will amplify the initial selection bias. Thus, if migrants are initially relatively skilled, then the least skilled will be more likely to return to their home country. Intuitively, if the initial selection bias is positive with the more skilled also more prone to migrate, then the least skilled will be the marginal migrants and will be more likely to reconsider their initial decision. Solimano (2002) reports that, at least in science and engineering, a large fraction of $\mathrm{PhD}$ graduates from developing countries remain in the United States after graduating. National Science Foundation data show that, four years after graduation, 88 percent of China's and 79 percent of India's graduates in science and engineering are still working in the United States. More comprehensive evidence comes from Massey and Lindstrom (1994) for Mexican migrants, Reagan and Olsen (2000) for the United States, Bauer and Gang (1998) for Egypt, and Steiner and Velling (1994) for Germany. For the Philippines, Rodriguez and Horton (1994) show

2. More direct evidence on the positive relationship between education and duration of stay comes from Reagan and Olsen (2000) for the United States. Similarly, the intended duration of stay is found to rise with education in Germany (Steiner and Velling 1994). Knerr (1994) also finds that for Pakistan skilled workers tend to stay longer abroad than unskilled workers. 
that returnees are somewhat less educated than those still abroad. Finally, Borjas (1989) shows that the least successful foreign scientists are more likely to return from the United States.

Further evidence on these issues is provided here for the European case using data for 1994-2001 from the European Community Household Panel. The focus is on foreign-born individuals with a view to assessing whether skilled migrants are more likely to reunite with their close family members and less likely to return home. For Europe as a whole and over the entire period lowskill individuals are less likely to be reunited with their spouse and live in the same dwelling (figure 1).

The European Community Household Panel is a closed panel and therefore cannot easily be used to study return migration. However, some useful insights come from an analysis of the pattern of attrition. To control for the possibility that factors other than migrants' choice to return home may affect attrition, panel attrition is assumed to be due either to the unwillingness of respondents to be interviewed again or to their choice to move to a different location, possibly to their home country. Accordingly, included among the regressors are the number of visits for the interview (under the plausible assumption that individuals are more likely to drop out of the panel when interviews are very time consuming) and a set of time-dependent dummy variables for the immigrant's region of origin to capture the effect that changing conditions in the home

Figure 1. Family Reunification Among Foreign-Born Individuals (Percentage of Households in which Spouses are Reunited)

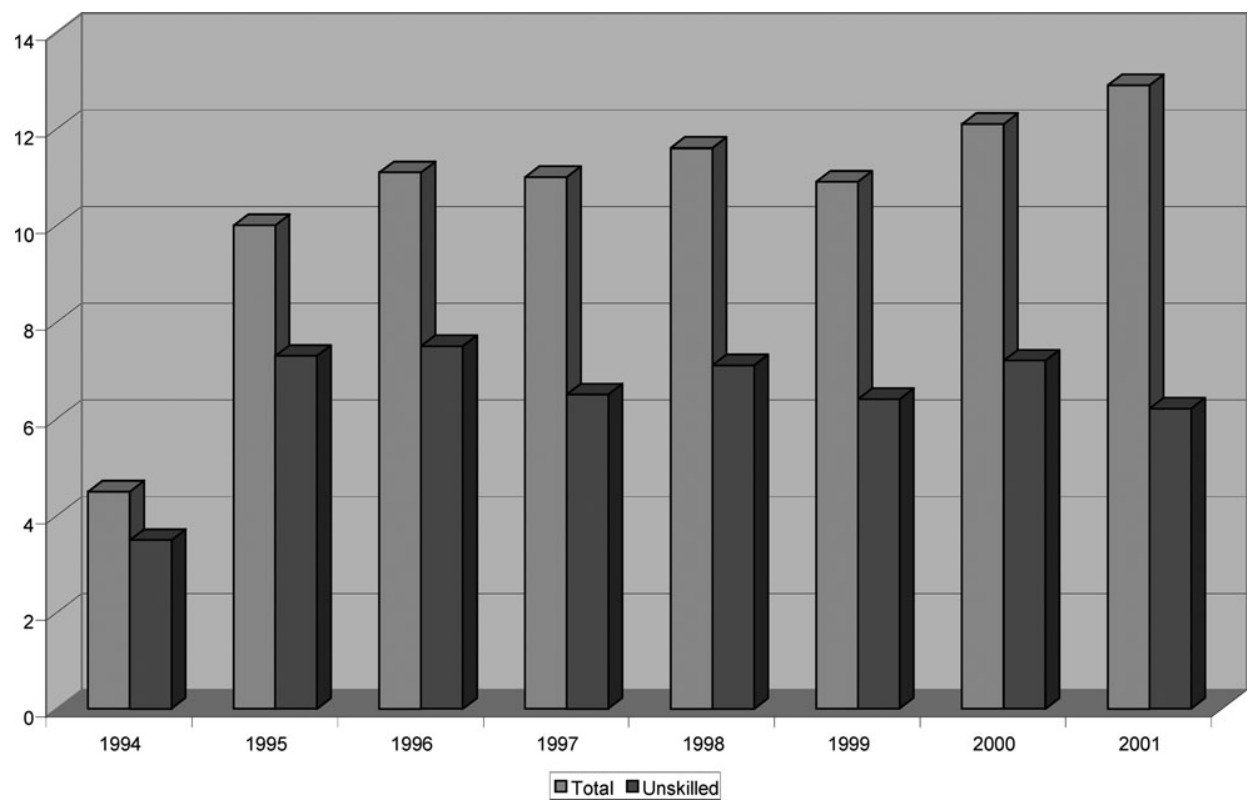

Source: Author's analysis based on data from the European Community Household Panel. 
country might have on the decision to return. A simple equation is estimated in which the probability of an immigrant remaining in (not dropping out of) the panel is a function of individual and household characteristics. Finally, separate equations are estimated for natives, immigrants from other EU countries, and non-EU immigrants.

The key finding (table 1, column 3 ) is that more educated immigrants from non- EU countries are less likely to drop out of the panel, even after controlling for age, gender, employment status, and length of stay in the host country. This finding may be taken to indicate that educated (non-EU) immigrants are less likely to return home, consistent with the notion that skilled migrants tend to stay longer in the host country. However, it may also be interpreted as showing that educated immigrants are less reluctant to be interviewed again. Which explanation holds is difficult to determine. What can be said, however,

Table 1. The Pattern of Attrition in the European Community Household Panel Sample (dependent variable: probability that respondent does not drop out of the panel)

\begin{tabular}{|c|c|c|c|}
\hline Variable & Natives & $\begin{array}{c}\text { EU } \\
\text { immigrants }\end{array}$ & $\begin{array}{l}\text { Non-EU } \\
\text { immigrants }\end{array}$ \\
\hline Household size & $0.012 * * *$ & 0.019 & $0.025 *$ \\
\hline Age & $-0.010 * * *$ & $-0.012 * * *$ & $-0.008 * * *$ \\
\hline Highest education & $0.034 * * *$ & 0.063 & $0.120 *$ \\
\hline Intermediate education & 0.005 & 0.032 & $0.104 *$ \\
\hline Gender & $0.062 * * *$ & $0.099 *$ & $0.168 * * *$ \\
\hline Employment & $0.108 * * *$ & 0.007 & $0.145^{* * *}$ \\
\hline Spouse & $0.282 * * *$ & $0.249 * * *$ & $0.241 * * *$ \\
\hline Visits $^{\mathrm{a}}$ & $-0.043 * * *$ & $-0.055 * *$ & $-0.022 *$ \\
\hline Minutes $^{\mathrm{b}}$ & 0.000 & 0.002 & -0.002 \\
\hline \multicolumn{4}{|l|}{ Immigrant } \\
\hline \multicolumn{4}{|l|}{ Immigrant EU } \\
\hline \multicolumn{4}{|l|}{ Immigrant non-EU } \\
\hline Length $^{\mathrm{c}}<5$ years & & $0.416 * * *$ & $0.538 * * *$ \\
\hline Length $^{\mathrm{c}} 6-15$ years & & $0.447 * * *$ & $0.567 * * *$ \\
\hline Length $^{\mathrm{c}} 16-25$ years & & $0.689 * * *$ & $0.846 * * *$ \\
\hline Constant & Yes & Yes & Yes \\
\hline Country dummy variable & Yes & Yes & Yes \\
\hline Time* origin & Yes & Yes & Yes \\
\hline Time dummy variable & Yes & Yes & Yes \\
\hline Number of observations & 345,830 & 6,041 & 7,823 \\
\hline Number of observations censored & 40,786 & 870 & 1,208 \\
\hline
\end{tabular}

$* p<0.05 ; * p<0.01 ; * * p<0.001$.

${ }^{\mathrm{a}}$ Number of visits to complete the interview at time $\mathrm{t}-1$.

${ }^{b}$ Length of the interview at $\mathrm{t}-1$.

'Immigrant's length of stay in the host country.

Source: Author's analysis based on data from the European Community Household Panel, 1994-2001. 
is that this effect is quantitatively much stronger for immigrants than for natives. More crucially, the overall effect of the home country time dummy variable is strongly significant, suggesting that conditions at home influence the attrition outcome.

\section{Remittances and The Brain Drain: A Simple Model}

This evidence is consistent with the notion that skilled migrants stay longer in the host country and are more likely to reunite with close family members. The implications of these findings for remittances are illustrated with the help of a simple model.

Assume that the household is composed of two groups, one very close to the migrant and the other less close. Only close family members are assumed to reunite with the migrant in the host country. The size of each group is normalized to one. Thus, in what follows, $f_{\mathrm{R}}$ (with $0 \leq f_{\mathrm{R}} \leq 1$ ) is both the percentage and the number of close family members who live with the migrant abroad. Also, let $C_{\mathrm{D}}$ denote the consumption of distant family members, $C_{\mathrm{H}}$ of close family members who stay at home, and $C_{R}$ of close family members who have reunited with the migrant. Finally, assume that the utility of a (altruistic) migrant can be represented as follows:

$$
U=U\left(C_{\mathrm{M}}, f_{\mathrm{R}}\right)+f_{\mathrm{R}} V^{\mathrm{C}}\left(C_{\mathrm{R}}\right)+\left(1-f_{\mathrm{R}}\right) V^{\mathrm{C}}\left(C_{\mathrm{H}}\right)+V^{\mathrm{D}}\left(C_{\mathrm{D}}\right)
$$

where $C_{M}$ is the migrant's own consumption. Migrants therefore derive utility from their own consumption and the consumption of their nonmigrating close relatives $\left[\left(1-f_{\mathrm{R}}\right) V^{\mathrm{C}}\left(C_{\mathrm{H}}\right)\right]$, of those who reside abroad with them $\left[f_{\mathrm{R}} V^{\mathrm{C}}\left(\mathrm{C}_{R}\right)\right]$, and of their more distant relatives $\left[V^{\mathrm{D}}\left(C_{\mathrm{D}}\right)\right]$.

There are two key assumptions. First, migrants also enjoy the proximity of their close family: their utility therefore is increasing in $f_{\mathrm{R}}-U_{\mathrm{f}}>0$. Second, for a given $C$, both the level and the marginal value of the migrant's utility are relatively larger for the close family members:

$$
V^{\mathrm{C}}(C)>V^{\mathrm{D}}(C) \text { and } V^{\mathrm{C}^{\prime}}(C)>V^{\mathrm{D}^{\prime}}(C) .
$$

There are four budget constraints. One is for the migrant:

$$
C_{\mathrm{M}}=w-\left[f_{\mathrm{R}} R_{\mathrm{R}}+\left(1-f_{\mathrm{R}}\right) R_{\mathrm{H}}+R_{\mathrm{D}}\right]-\theta f_{\mathrm{R}}
$$

where $w$ denotes the migrant's wage, $R_{i}$ remittances to group $i$, and $\theta$ the cost for the migrant of bringing relatives to the host country. The migrant's consumption is then equal to the migrant's wage minus the sum of remittances and reunification costs. The other three budget constraints are for each of 
the three other household groups:

$$
C_{i}=Y_{i}+R_{i} \quad i=\mathrm{R}, \mathrm{H}, \mathrm{D}
$$

where household members have two sources of revenue, their own income $\left(Y_{i}\right)$ and remittances $\left(R_{i}\right)$.

The first-order condition with respect to remittances to, say, nonmigrating close household members $\left(R_{\mathrm{H}}\right)$, can be written as:

$$
\begin{aligned}
& -\left(1-f_{\mathrm{R}}\right) U_{\mathrm{C}}\left(C_{\mathrm{M}}, f_{\mathrm{R}}\right)-\left(1-f_{\mathrm{R}}\right) V^{\mathrm{C}^{\prime}}\left(Y_{\mathrm{H}}+R_{\mathrm{H}}\right)=0 \rightarrow U_{\mathrm{C}}\left(C_{\mathrm{M}}, f_{\mathrm{R}}\right) \\
& =V^{\mathrm{C}^{\prime}}\left(Y_{\mathrm{H}}+R_{\mathrm{H}}\right)
\end{aligned}
$$

After deriving analogous conditions for $R_{\mathrm{R}}$ and $R_{\mathrm{D}}$, this becomes:

$$
U_{\mathrm{C}}\left(C_{\mathrm{M}}, f_{\mathrm{R}}\right)=V^{\mathrm{C}^{\prime}}\left(Y_{\mathrm{H}}+R_{\mathrm{H}}\right)=V^{\mathrm{C}^{\prime}}\left(Y_{\mathrm{R}}+R_{\mathrm{R}}\right)=V^{\mathrm{D}^{\prime}}\left(Y_{\mathrm{D}}+R_{\mathrm{D}}\right)
$$

Because of equation (2), this implies:

$$
\left(Y_{\mathrm{H}}+R_{\mathrm{H}}\right)=\left(Y_{\mathrm{R}}+R_{\mathrm{R}}\right)>\left(Y_{\mathrm{D}}+R_{\mathrm{D}}\right) .
$$

Then, unless $Y_{\mathrm{D}}$ is significantly smaller than $Y_{\mathrm{H}}$ (a somewhat implausible case, given that $Y_{\mathrm{H}}$ will typically fall following the migration of one of the migrant's close relatives), remittances to close nonmigrating household members $\left(R_{\mathrm{H}}\right)$ will be larger than those to distant family members $\left(R_{\mathrm{D}}\right)$.

Given equation (6), the first-order condition with respect to $f_{\mathrm{R}}$ reads simply as:

$$
-U_{\mathrm{C}} \theta+U_{\mathrm{f}}=0 \rightarrow \frac{U_{\mathrm{f}}}{U_{\mathrm{c}}}=\theta
$$

which states that the marginal rate of substitution between $f_{\mathrm{R}}$ and $C_{\mathrm{M}}$ must be equal to its cost. This condition plays a key role in the results, as shown subsequently.

Now consider the impact of a higher skill content of migration. Migrants with higher skills will typically earn a higher wage abroad. From equations (1) and (3) it can easily be seen that an increase in $w$ will, for a given flow of remittances and an unchanged value of $f_{\mathrm{R}}$, lead to a rise in the migrant's own consumption $\left(C_{M}\right)$ and, as a result, to a fall in the marginal utility of $C_{M}$. Thus, $U_{\mathrm{f}} / U_{\mathrm{C}}$ will be greater than $\theta$. For a new equilibrium to obtain, the degree of family reunification will also have to rise, so as to bring $U_{\mathrm{f}} / U_{\mathrm{C}}$ back in line with $\theta$. As claimed, (high wage) skilled migrants will therefore be more likely to reunite with their family. 
What about remittances? Given equation (6), in the new equilibrium both $V^{\mathrm{C}^{\prime}}$ and $V^{\mathrm{D}^{\prime}}$ will need to fall and, as a result, for a given set of $Y_{i}^{\prime}$ 's, remittances to all groups $(\mathrm{H}, \mathrm{R}$, and $\mathrm{D})$ will increase. ${ }^{3}$ However, the fact that both $R_{\mathrm{H}}$ and $R_{\mathrm{D}}$ will increase does not necessarily imply that the total flow of "actual" remittances will increase. ${ }^{4}$ Indeed, there will be two effects. First, as just noted, the amount of per capita remittances will rise for both nonmigrating close and distant family members (the "wage" effect). Second, a larger share of close family members will reunite with the migrant. The composition of nonmigrating members will therefore shift toward the low-remittance group-the distant family members (the "reunification" effect ${ }^{5}$ ). If the reunification effect is stronger than the wage effect, per capita remittances to nonmigrating household members will decline. The model does not provide an unambiguous answer in this respect. Only empirical analysis can resolve such ambiguity. Finally, the impact of higher income at home can also be examined. If $Y_{i}$ rises, the marginal utility of remittances to group $i$ will fall. Remittances will therefore decline.

\section{Remittances and The Brain Drain: ECONOMETRIC EVIDENCE}

Empirical analysis of the brain drain has been hampered by the lack of comprehensive and comparable data. With the pioneering work of Carrington and Detragiache (1998) and the contributions of Dumont and Lemaître (2004) and Docquier and Marfouk (2004), however, this gap is being filled. Carrington and Detragiache (1998) rely on the 1990 U.S. Census to estimate the number of skilled migrants to the United States from a large set of sending countries. For non-U.S. destinations they have information only on the total number of migrants. They address this shortcoming by assuming that migrants to non-U.S. OECD destinations have the same skill composition as migrants to the United States. Obviously, their origin country data on the brain drain are a valid approximation only for countries that send most of their migrants to the United States. Docquier and Marfouk (2004) overcome this limitation by using national sources of data for destinations other than the United States to estimate the skill composition of migrants. ${ }^{6}$ Finally, both Carrington and

3. More formally, $R_{i}$ and $f_{\mathrm{R}}$ will increase following a rise in $w$ if they are both normal goods: $U_{i k}-$ $U_{k k} U_{i} / U_{k}>0$

4. The focus next is on "actual" remittances, or the amount of transfers to nonmigrating household members $\left(R_{\mathrm{H}}\right.$ and $\left.R_{\mathrm{D}}\right)$. Indeed, $R_{\mathrm{R}}$ (the remittances to close family members who have already reunited with the migrant) is simply an intrahousehold transfer and does not generate any foreign exchange inflow for the home country.

5. Reunification may well be dictated by immigration laws in the host country. But reunification procedures are typically quite generous in most destination countries. Moreover, migrants have considerable leeway in selecting which close family members to bring to the host country. Migrants may also select the host country based on its provisions for family reunification. Overall, therefore, reunification is likely to be largely exogenous.

6. Docquier and Marfouk (2004) also extend the Carrington and Detragiache dataset to 2000. 
Detragiache (1998) and Docquier and Marfouk (2004) relate the total number of skilled migrants to the Barro and Lee (2001) data set on educational achievements to derive a measure of migration rates for skilled workers, here defined as migrants having completed tertiary education.

The following relies on the Docquier and Marfouk (2004) data set to investigate the relationship between remittances and skilled migration. Remittance data come from the International Monetary Fund (IMF, various years) and include workers remittances, compensation of employees, and capital transfers. Population and income data come from the World Bank (2005). Docquier and Marfouk provide data for 1990 and 2000 on the level and composition of migration. Remittance data are averaged over 1990-91 and 2000-01. The estimating equation is inspired by the model described in section II. $^{7}$ Two groups of migrants are distinguished, skilled (S) and unskilled (U), with remittances of skilled workers denoted by $R_{\mathrm{S}}$ and of unskilled workers by $R_{\mathrm{U}}$. Total remittances are therefore identically equal to:

$$
R \equiv m_{\mathrm{s}} R_{\mathrm{s}}+m_{\mathrm{U}} R_{\mathrm{U}}
$$

where $m_{i}$ denotes the number of migrants in group $i$. To implement the model, detailed information is needed on the degree of family reunification and the number of close and distant relatives. While such data are unavailable, an estimating equation can nonetheless be derived. The model suggests that for both skilled and unskilled migrants remittances are a function of the migrant's wage and the income of the migrant's family members, leading to the following behavioral equation:

$$
R_{i}=\alpha_{i} w_{i}-\beta_{i} y_{i} \quad i=\mathrm{S}, \mathrm{U}
$$

where $w_{i}$ denotes the wage level of migrant $i, y_{i}$ denotes the per capita income of household members, and $\alpha_{i}>0$ for $i=\mathrm{S}, \mathrm{U}$ is the propensity to remit. With altruism, remittances should be a declining function of $y_{i}$ (the income of those left behind). Thus, it is expected that $\beta_{i}>0$ for $i=\mathrm{S}, \mathrm{U}$, where $\beta_{i}>0$ measures the degree of altruism. In equation (10), under the assumption that the reunification effect applies mainly to skilled migrants, $\alpha_{\mathrm{S}}<\alpha_{\mathrm{U}}$. Common sense and human capital theory permit the assumption that $w_{\mathrm{S}}>w_{\mathrm{U}}$. If the reunification effect is stronger than the wage effect, it could well be that $\alpha_{\mathrm{S}} w_{\mathrm{S}}<\alpha_{\mathrm{U}} w_{\mathrm{U}}$. In the absence of information about the functional form of equation (10), a linear relationship is postulated in the estimation and then a log-linear functional form.

7. The results differ from those in Faini (2002) for two main reasons: a different and broader data set is used and the estimating equation is more closely related to theory. 
An additional hurdle arises because there is no separate information on the wage level of skilled and unskilled migrants $\left(w_{i}\right)$ or on the income of their household members $\left(y_{i}\right)$. Nonetheless, equation (10) can be substituted for $I=$ $\mathrm{S}, \mathrm{U}$ in equation (9) to estimate an aggregate equation. After some simple algebra, that yields:

$$
\begin{aligned}
\frac{R}{P}= & \alpha_{\mathrm{U}} w_{\mathrm{U}} \frac{M}{P}+\left(\alpha_{\mathrm{S}} w_{\mathrm{S}}-\alpha_{\mathrm{U}} w_{\mathrm{U}}\right) \frac{m_{\mathrm{S}}}{P} \\
& -\beta_{\mathrm{U}}\left(1-p_{\mathrm{S}} \frac{y_{\mathrm{S}}}{Y}\right) \frac{m_{\mathrm{U}}}{p_{\mathrm{U}}} \frac{Y}{P}-\beta_{\mathrm{S}} p_{\mathrm{S}} \frac{y_{\mathrm{S}}}{Y} \frac{m_{\mathrm{S}}}{p_{\mathrm{S}}} \frac{Y}{P}
\end{aligned}
$$

where $M\left(=m_{\mathrm{S}}+m_{\mathrm{U}}\right)$ is total migration, $P\left(=p_{\mathrm{S}}+p_{\mathrm{U}}\right)$ is total population, and $Y\left(=p_{\mathrm{S}} y_{\mathrm{S}}+p_{\mathrm{U}} y_{\mathrm{U}}\right)$ is total income in the home country. Equation (11) can be estimated by regressing per capita remittances $(R / P)$ on the total stock of migrants abroad relative to population $(M / P)$, the ratio of skilled migrants to the home country population $\left(m_{S} / P\right)$, and income per capita times the migration rate of unskilled workers $\left(m_{\mathrm{U}} / p_{\mathrm{U}} Y / P\right)$ and skilled workers $\left(m_{\mathrm{S}} / p_{\mathrm{S}} Y / P\right)$. The major shortcoming of this approach is the need to assume that the unobservable distributional share parameters, $\tau_{\mathrm{U}} \equiv\left(1-p_{\mathrm{S}} y_{\mathrm{S}} / Y\right), \tau_{\mathrm{S}} \equiv\left(p_{\mathrm{S}} y_{\mathrm{S}} / Y\right)$ are invariant across countries.

As a first step, figure 2 reports the scatter plot of per capita remittances on the share of skilled migrants in the total stock of migrants, showing the linear fit between the two variables with the associated 95 percent confidence

Figure 2. Per Capita Remittances and the Share of Skilled Migrants

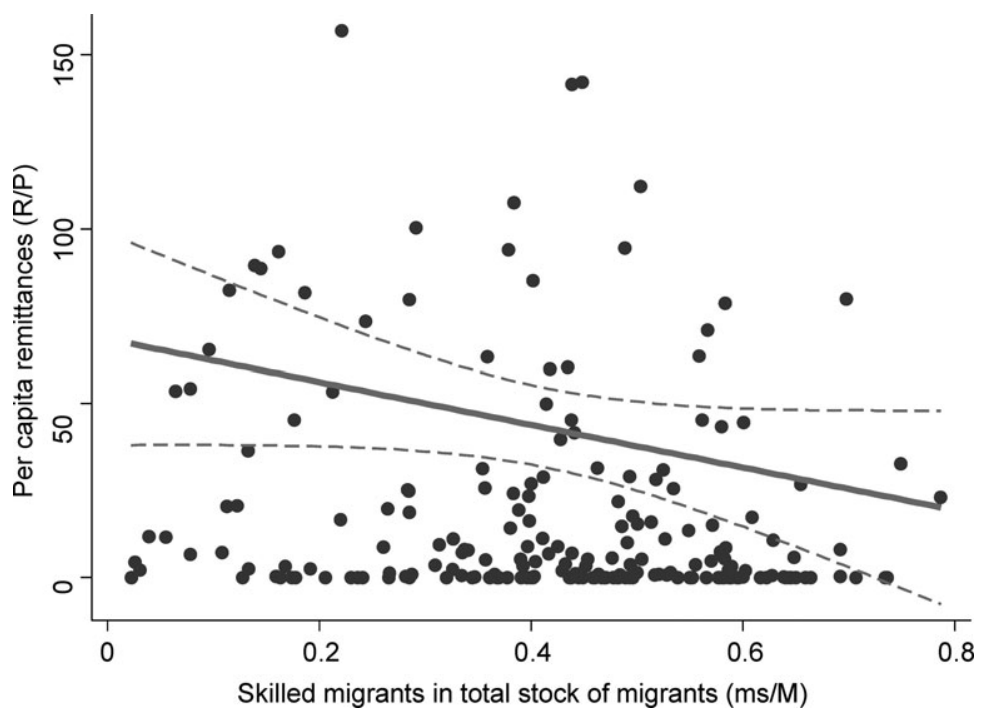

Source: Author's analysis based on data from Docquier and Marfouk (2004). 
interval. The slope is significantly negative at a 10 percent significance level. This preliminary inspection suggests that a larger share of skilled migrants is associated with a lower remittance flow.

Estimation of equation (11) leads to:

$$
\begin{aligned}
\left(\frac{R}{P}\right)_{i t}= & \gamma_{0}+\gamma_{1}\left(D_{t} \frac{M}{P}\right)_{i t}+\gamma_{2}\left(\frac{M}{P}\right)_{i t} \\
& +\gamma_{3}\left(\frac{m_{\mathrm{S}}}{P}\right)_{i t}+\gamma_{4}\left(\frac{m_{\mathrm{U}}}{p_{\mathrm{U}}} \frac{Y}{P}\right)_{i t}+\gamma_{5}\left(\frac{m_{\mathrm{S}}}{p_{\mathrm{S}}} \frac{Y}{P}\right)_{i t} \\
& +\varepsilon_{i t} \quad i=1, \ldots, 188 \quad t=1990,2000
\end{aligned}
$$

where $D_{t}=1$ if $t=2000$; the expected signs are $\gamma_{2}=\alpha_{\mathrm{U}} w_{\mathrm{U}}>0, \gamma_{3}=\alpha_{\mathrm{S}} w_{\mathrm{S}}-$ $\alpha_{\mathrm{U}} w_{\mathrm{U}} \lessgtr 0, \gamma_{4}=-\beta_{\mathrm{U}} \tau_{\mathrm{U}}<0$, and $\gamma_{5}=-\beta_{\mathrm{S}} \tau_{\mathrm{S}}<0$; and $\varepsilon_{i t}$ is a stochastic error term.

Equation (12) is first estimated separately for each period. Data are then pooled after testing that the relevant coefficients are constant across time and that pooling is appropriate. In the pooled equation a dummy variable $D_{t}$ (which takes the value of one in the year 2000) is added to control for possible time effects. The coefficient on the stock of migrants is expected to be higher in 2000, since wages are likely to have increased between 1990 and 2000. In an experiment with an alternative specification the time dummy variable is interacted with the migration stock variable $\left(\gamma_{1}>0\right)$. The pooled estimates are presented in column 1 of table $2 .^{8}$ The pooling restriction is not rejected by the data at the 5 percent significance level, with $\mathrm{F}(4,178)=0.94$.

Generally speaking, the coefficients have the expected sign. Most are significantly different from zero at standard statistical levels. Total migration has a positive sign, as expected. All else being equal, therefore, an increase in the stock of the migrant population relative to the home country population $(M / P)$ will be associated with a larger flow of remittances. The coefficient of $m_{\mathrm{S}} / P$ is negative, but not significantly different from zero. This coefficient is crucial for the analysis. As shown, $\left(\alpha_{\mathrm{S}} w_{\mathrm{S}}-\alpha_{\mathrm{U}} w_{\mathrm{U}}\right)$ could be of either sign depending on whether the wage effect is stronger or weaker than the reunification effect. The negative nonsignificant sign indicates that the reunification effect is stronger than the wage effect $-\alpha_{\mathrm{S}}<\alpha_{\mathrm{U}}$. Finally, the estimates suggest that $\gamma_{4}>0$ and that $\gamma_{5}<0$. The degree of altruism, as measured by the coefficient $\beta_{i}$, is positive for skilled workers but negative for unskilled workers. When the fact that 64 of 188 observations are censored at zero (using the Tobit maximum likelihood estimation procedure) is taken into account, the results are basically

8. Only the specification with the time dummy variable interacted with the migration stock variable is reported. 
TAвle 2. Remittances and the Skill Composition of Migration

\begin{tabular}{|c|c|c|c|c|c|}
\hline & $\begin{array}{c}(1) \\
(R / P)\end{array}$ & $\begin{array}{c}(2) \\
(R / P)\end{array}$ & $\begin{array}{c}(3) \\
(R / P)\end{array}$ & $\begin{array}{c}(4) \\
\ln (R / P)\end{array}$ & $\begin{array}{c}(5) \\
\ln (R / P)\end{array}$ \\
\hline Estimator & $\begin{array}{c}\text { Pooled } \\
\text { ordinary least } \\
\text { squares }\end{array}$ & Tobit & $\begin{array}{c}\text { Pooled } \\
\text { ordinary } \\
\text { least squares } \\
\text { with } R>0\end{array}$ & $\begin{array}{c}\text { Pooled } \\
\text { ordinary } \\
\text { least squares }\end{array}$ & $\begin{array}{l}\text { Instrumental } \\
\text { variable }\end{array}$ \\
\hline$(D, M / P)$ & $1.2(0.8)$ & $1.1(0.7)$ & $3.6(0.4)$ & $0.02(1.19)$ & $0.07(1.62)$ \\
\hline$(M / P)$ & $3.7(2.2)$ & $4.3(2.4)$ & $3.8(2.3)$ & $0.36(8.20)$ & $0.47(3.0)$ \\
\hline$\left(m_{\mathrm{S}} / P\right)$ & $-1.96(0.22)$ & $-0.9(0.1)$ & $-1.7(0.2)$ & $-0.09(1.1)$ & $-0.21(1.42)$ \\
\hline$\left(m_{\mathrm{U}} / p_{\mathrm{U}} Y / P\right)$ & $0.15(2.62)$ & $0.17(2.8)$ & $0.13(2.1)$ & & \\
\hline$\left(m_{\mathrm{S}} / p_{\mathrm{S}} Y / P\right)$ & $-0.017(3.5)$ & $-0.025(3.7)$ & $-0.014(1.5)$ & & \\
\hline$\left(m_{\mathrm{U}} / p_{\mathrm{U}}\right) \ln (Y / P)$ & & & & $-2.49(4.2)$ & $-4.24(1.93)$ \\
\hline$\left(m_{\mathrm{S}} / p_{\mathrm{S}}\right) \ln (Y / P)$ & & & & $-0.77(6.3)$ & $-0.87(3.7)$ \\
\hline$R^{2}$ & 0.63 & 0.62 & 0.63 & 0.45 & 0.42 \\
\hline $\begin{array}{l}\text { Number of } \\
\text { observations }\end{array}$ & 188 & 188 & 134 & 134 & 134 \\
\hline
\end{tabular}

$R$ is total remittances, $M$ is migration stock, $P$ is home country's population, $m_{\mathrm{S}}$ is skilled migrants, $m_{\mathrm{U}}$ is unskilled migrants, $p_{\mathrm{S}}$ is home country's skilled population, $p_{\mathrm{U}}$ is home country's unskilled population, $Y$ is GDP, and $t$ is time effect.

Note: Numbers in parentheses are $t$-statistics corrected for heteroskedasticity.

Source: Author's analysis based on data from Docquier and Marfouk (2004).

unchanged (column 2) with respect to those in column 1, and they remain so even if the sample is restricted to observations with $R>0$ (column 3 ). ${ }^{9}$

Next, some curvature is introduced in the relationship between remittances and home income. To check the reobustness of the linear functional form of equation (10), several alternative functional specifications are tested. Remittances are again found to be positively affected by a larger stock of migrants, and the population share of skilled migrants carries a negative coefficient, although it is statistically insignificant. The degree of altruism of both skilled and unskilled workers is now found to be positive. Note that if it is assumed that $\beta_{\mathrm{U}}=\beta_{\mathrm{S}}$-that altruism between skilled and unskilled migrants is equal-the distributional parameter can easily be computed: $\tau_{\mathrm{S}} \equiv\left(p_{\mathrm{S}} y_{\mathrm{S}} / Y\right)=$ 0.24 , a somewhat large but not unreasonable value.

Finally, to control for the possibility that the total migration rate is endogenous, the equation is re-estimated with an instrumental variable procedure using the $\log$ of distance between the home and the host country as an instrument. ${ }^{10}$

9. In response to suggestions by a referee, a dummy variable for small island countries $\left(m_{\mathrm{S}} / P\right)$ was introduced both additively and multiplicatively to capture the possibility that remittances are measured less accurately for these countries, which have the largest brain drain, thereby mechanically leading to a negative relation between $\left(m_{\mathrm{S}} / P\right)$ and remittances. Estimated coefficients remained unchanged. The results are also unchanged when the regression is estimated only for 2000 and when income per capita in the source country is introduced by itself as an additional variable.

10. A weighted average of distance to the European Union and the United States is used, with weights reflecting the relative importance of these two destinations. 
While distance is typically a major determinant of migration, it should not affect a financial flow such as remittances, making it an adequate instrument. The $\mathrm{R}^{2}$ of the first-stage regression is 0.96, and the $\mathrm{F}$ statistics is 685.8 . Distance is a significant determinant of migration, suggesting that it contains considerable additional and, one hopes, exogenous information. In the secondstage regression (reported in column 5 of table 2), all previous results carry through and, if anything, are even stronger in both coefficient size and statistical significance. However, it could be that financial remittances are inversely related to distance, in which case distance would not be a valid instrument.

\section{Conclusions}

It is often argued that the negative impact of the brain drain might be mitigated by its favorable effect on remittances. This article has shown that this is not generally true. This is both because skilled migrants are more likely to come from wealthier families and because their propensity to remit is relatively lower, presumably reflecting the fact that they are keener (and more able) to bring their closest relatives to the host country. The findings of this article need to be confirmed by further research, especially at the household level. Globally, they show that the migration of skilled workers is unlikely to boost the flow of remittances to the source country. However, this finding assumes that the migration of skilled workers occurs as a one-for-one substitute for unskilled migration. While this appears to be the hope of some policymakers, in practice the total level of migration may increase as skilled migration increases. The extent to which skilled migration may substitute for or complement unskilled migration remains an open question for future research.

\section{REFERENCES}

Adams, R. 1991. "The Economic Uses and Impact of International Remittances in Rural Egypt." Economic Development and Cultural Change 39(4):695-722.

- 1998. "Remittances, Investment and Rural Asset Accumulation in Pakistan." Economic Development and Cultural Change 47(1):155-73.

Barro, R.J., and J.W. Lee. 2001. "International Data on Educational Attainment: Updates and Implications." Oxford Economic Papers 53(3):541-63.

Bauer, T., and I. Gang. 1998. "Temporary Migrants from Egypt: How Long Do They Stay Abroad?" Discussion Paper 3. Bonn, Germany: Institute for the Study of Labor, Bonn University.

Beine, M., F. Docquier, and H. Rapoport. 2001. "Brain Drain and Economic Growth: Theory and Evidence." Journal of Development Economics 64(1):275-89.

- 2003. "Brain Drain and LDCs' Growth: Winners and Losers." Discussion Paper 819. Bonn, Germany: Institute for the Study of Labor, Bonn University.

Bhagwati, J. 1976. "The International Brain Drain and Taxation: A Survey of the Issues." In J. Bhagwati ed., The Brain Drain and Taxation II: Theory and Empirical Analysis. Amsterdam: North-Holland. 
Bhagwati, J., and K. Hamada. 1974. "The Brain, International Integration of Markets for Professionals, and Unemployment: A Theoretical Analysis.” Journal of Development Economics 1(1):19-24.

Borjas, G. 1989. "Immigrant and Emigrant Earnings: A Longitudinal Study." Economic Inquiry 27(1):21-37.

Borjas, G., and B. Bratsberg. 1996. "Who Leaves? The Outmigration of the Foreign-Born." Review of Economics and Statistics 78(1):165-76.

Carrington, W., and E. Detragiache. 1998. “How Big Is the Brain Drain?” IMF Working Paper 98/102. Washington, D.C.: International Monetary Fund.

Chami, R., C. Fullenkamp, and S. Jahjah. 2003. “Are Immigrant Remittance Flows a Source of Capital for Development?” IMF Working Paper 03/189. Washington, D.C.: International Monetary Fund.

Docquier, F., and A. Marfouk. 2004. "Measuring the International Mobility of Skilled Workers (19902000).” Policy Research Working Paper 3381. World Bank, Washington, D.C.

Docquier, F., O. Lohest, and A. Marfouk. 2007. "Brain drain in developing countries." World Bank Economic Review 21(2); doi:10.1093/wber/lhm008.

Dumont, J.C., and G. Lematre. 2004. "Counting Immigrants and Expatriates in OECD Countries: A New Perspective." Social, Employment and Migration Working Papers 25. Paris: OECD Directorate for Employment, Labour, and Social Affairs.

Faini, R. 2002. "Development, Trade, and Migration." Revue d'Économie et du Développement, Proceedings from the ABCDE Europe Conference 1-2: 85-116.

IMF (International Monetary Fund). Various years. Balance of Payments Statistics Yearbook. Washington, D.C.

Johnson, G., and W. Whitelaw. 1974. "Urban-Rural Income Transfers in Kenya: An Estimated Remittances Function.” Economic Development and Cultural Change 22(3):473-79.

Knerr, B. 1994. "Labour Migration from South Asia: Patterns and Economic Implications." In D. O’Connor and L. Farsakh, eds., Development Strategy, Employment and Migration. Country Experiences. Paris: OECD Development Centre.

Lucas, R.E.B., and O. Stark. 1985. "Motivations to Remit: Evidence from Botswana." Journal of Political Economy 93(5):901-18.

Massey, D., and D. Lindstrom. 1994. "Selective Emigration, Cohort Quality, and Models of Immigrant Assimilation.” Social Science Research 23(4):315-49.

Mountford, A. 1997. "Can a Brain Drain Be Good for Growth in the Source Economy?" Journal of Development Economics 53(2):287-303.

OECD (Organisation for Economic Co-operation and Development). 2003. Economic Outlook. Paris: OECD.

Rajan, R., and A. Subramanian. 2005a. Aid and Growth: What Does The Cross-Country Evidence Really Show? NBER Working Paper 11513. Cambridge, Mass.: National Bureau of Economic Research.

- 2005b. What Undermines Aid's Impact on Growth? NBER Working Paper 11657. Cambridge, Mass.: National Bureau of Economic Research.

Reagan, P., and R. Olsen. 2000. "You Can Go Home Again: Evidence from Longitudinal Data." Demography 37(3):339-50.

Rempel, H., and R. Lobdell. 1978. "The Role of Urban-to-Rural Remittances in Rural Development." Journal of Development Studies 14(3):324-41.

Rodriguez, E., and S. Horton. 1994. "International Return Migration and Remittances in the Philippines." In D. O’Connor and L. Farsakh, eds., Development Strategy, Employment and Migration. Country Experiences. Paris: OECD Development Centre.

Solimano, A. 2002. "Globalizing Talent and Human Capital: Implications for Developing Countries." Paper presented at the Annual World Bank Conference on Development Economics for Europe, June 24-26, Oslo, Norway. 
Stalker, P. 1994. The Work of Strangers: A Survey of International Labour Migration. Geneva: International Labour Office.

Stark, O., C. Helmenstein, and A. Prskawetz. 1997. “A Brain Gain with a Brain Drain.” Economic Letters 55(2):227-34.

1998. "Human Capital Formation, Human Capital Depletion, and Migration: A Blessing or a 'Curse?’” Economic Letters 60(3):363-67.

Steiner, V., and J. Velling. 1994. "Re-migration Behaviour and Expected Duration of Stay of Guest Workers in Germany." In G. Steinmann and R. Ulrich eds., The Economic Consequences of Immigration to Germany. Heidelberg: Physica-Verlag.

World Bank. 2003. “Chapter 7.” Global Development Finance 2003: Striving for Stability in Development Finance. Washington, D.C.

- 2005. World Development Indicators 2005. Washington, D.C.

2006. Global Economic Prospects 2006: Economic Implications of Remittances and Migration. Washington, D.C. 